UDC 631.12.017.1/.3

COBISS.SR-ID: 220306444

Original research paper

Acta Agriculturae Serbica, Vol. XX, 40 (2015) 145-153

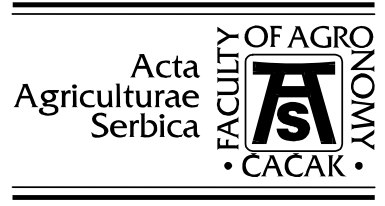

\title{
Application of IoT in monitoring and controlling agricultural production
}

\author{
Dušan Marković, Ranko Koprivica \\ Faculty of Agriculture, University of Kragujevac, \\ Cara Dušana 34, 32000 Čačak, Serbia \\ Uroš Pešović, Siniša Ranđić \\ Faculty of Technical Sciences, University of Kragujevac, \\ Svetog Save 65, 32000 Čačak, Serbia
}

\begin{abstract}
Internet of Things (IoT) is a concept that allows physical objects with computational and sensory support to connect with each other and access services across the Internet. The IoT idea was introduced to connect devices through the Internet and facilitate access to information for users. The wide range of potential applications of IoT also includes agriculture, where extensive use of IoT is expected in the future. The aim of this work was to present the IoT concept as a basis for monitoring and control systems used in farm production processes. IoT devices play a key role, with a focus on their realization by available microcontroller platforms and appropriate sensors such as Arduino products. Autonomous sensor devices gather data within monitoring systems and participate in the control process by sending signals to the actuators. Such an IoT based system provides users with the opportunity to remotely monitor conditions and production process. This system enables users to accomplish savings in inputs, achieve cost reduction and trace the production process on the farm.
\end{abstract}

Key words: Internet of Things, sensors, monitoring system, agriculture, farm. 


\section{Introduction}

Internet of Things (IoT) represents the idea of connecting physical objects, which have sensing, networking and computing capabilities, to other objects and services over the Internet. The basic concept underlying IoT is not new, but IoT uses various numbers and kinds of devices and their network interconnection across the Internet. This leads to big changes in terms of integrations in the existing network; therefore, the IoT concept ensures that each device is accessible through the Internet (Whitmore et al. 2014).

In the last decade, technological changes have also affected agricultural crop production and breeding of domestic animals. Through the use of various sensors and wireless devices, farmers can obtain information about soil humidity (Zhang et al. 2013), nutrient condition in the soil (Galande et al. 2015), or the occurrence of plant diseases and pests in plants (Dang et al. 2013). On the basis of the information received, farmers can react in a timely manner and apply appropriate measures. Data on the operation of agricultural machinery is obtained using sensors, which enable operators to adjust machine operation to working conditions in order to achieve higher effectiveness and quality of the production process.

IoT brings a new production view to traditional agriculture, and it is oriented to the information network involving automation, use of intelligent devices and their networking in the process of agricultural production.

Benefits of IoT applications in agriculture include improvement in the use efficiency of inputs such as soil, water, fertilizers, pesticides, etc., reduced cost of production, increased profitability, sustainability, food safety, environmental protection (Patil et al. 2012). Through IoT, farmers are able to deliver their crops to customers on a wide scale. This can change the supply chain in the way to provide a more directed and shorter chain from the point of production to the consumer.

The aim of this work was to present the IoT concept in the monitoring and control system model applied to farm production processes. Moreover, the main focus is on definitions of IoT devices and their realizations by available microcontroller platforms, with shields and appropriate sensors, such as Arduino products.

\section{Basis for the development of the system}

The realization of IoT nodes is based on Arduino platforms with available shields and compatible sensors, characterized by good library supports.

Nam et al. (2013) presented a gateway platform used to connect physical objects to the Internet. The proposed architecture was implemented on Arduino 
platforms and defines the creation of IoT services enabling local sensors to be accessed from LAN or the Internet.

Sensor devices based on Arduino offer their accessibility by connecting to LAN networks. This is achieved by integrating Ethernet or WiFi modules to sensor devices, thus allowing their interconnection. For that purpose, Arduino ENC28J60 Ethernet Module is used for Ethernet or ESP8266 Module for their wireless network connections.

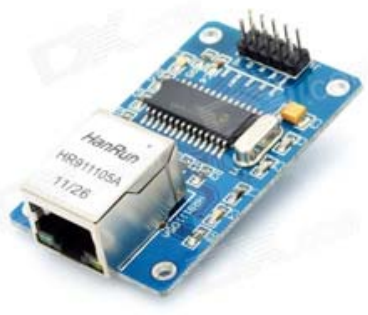

Figure 1. Arduino ENC28J60 Ethernet Module

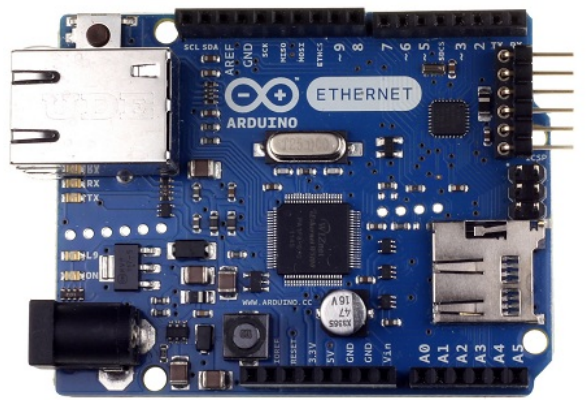

Figure 2. Arduino Ethernet Rev. 3 board

The Ethernet module (Figure 1) uses a new Microchip ENC28J60 to handle network protocol requirements. The module is connected to most microcontrollers by the SPI interface. It has a power supply of $+3.3 \mathrm{~V}$ and a transfer speed of up to $20 \mathrm{MHz}$ (ENC28J60 Ethernet).

Arduino Ethernet is shown in Figure 2. It features an Arduino development board, based on ATmega328, with Ethernet interface built in on the same board. This board is powered by external power supply, an optional PoE module or via FTDI cable/USB Serial connector (Arduino Ethernet).

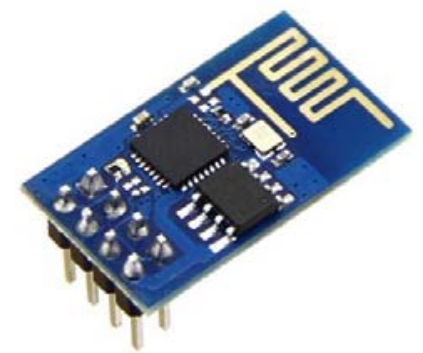

Figure 3. ESP8266 Wifi Module 
ESP8266 is a WiFi networking solution that enables connection of the microcontroller to the WiFi (Figure 3.). Also, it is capable of running separate applications independently. ESP8266 Module has the following specification characteristics: 3.3 power supply, RAM $32 \mathrm{~K}+80 \mathrm{~K}$, processor speed $80-160 \mathrm{MHz}$ and $802.11 \mathrm{~b} / \mathrm{g} / \mathrm{n} / \mathrm{d} / \mathrm{e} / \mathrm{i} / \mathrm{k} / \mathrm{r}$ supports. At full power, the transmitting current consumption can be $170 \mathrm{~mA}$ but in sleep mode it requires 10uA (Kolban, 2015). The battery power supply for this module may have a solar panel for recharging the battery.

\section{Application of Internet of Things devices}

The wide range of potential applications of IoT also includes intelligent agriculture, where extensive use of IoT is expected in the future.

Zhao et al. (2010) studied the integration of IoT technology in information systems and control networks applied in real farming scenarios. The main goal of the greenhouse technology is the highest possible level of automation which includes a monitoring system with internet and wireless devices combined. Research results on the use of the greenhouse monitoring system based on IoT technology show precision in the monitoring and control process. The automatic control system provides appropriate growth conditions in the greenhouse.

Ma et al. (2011) presented the design of a sensor network which connects agriculture and IoT. In this system, design connections can be established among agricultural experts, farmers and crops regardless of their geographic locations. This system offers considerable reliability, interoperability, low cost and management.

Zhou et al. (2012) analyzed IoT in terms of data collection, network service, data fusion and computation in intelligent agriculture. They presented the production monitoring system of agricultural standardization based on IoT which enables real time, remote and accurate parameters of agricultural environment.

Article Shi et al. (2015) presented the concept of IoT technology used in controlling plant diseases and insect pests, which consist of a monitoring system to collect pest information using sensor nodes and data processing components.

Paper Chen (2015) presented the design of an autonomous tracing system based on the Internet of Things architecture. As safety and quality food issues are mostly dependent on their handling process, there has been a huge interest in developing the food supply chain traceability system. The use of new technologies such as IoT and software agents is an appropriate tool for the exchange of electronic tracing information among actors in the food supply chain. The use of this tool is beneficial in reducing tracing time, and it provides an autonomous tracing operation.

Minbo et al. (2013) introduced the implementation of information services based on IoT distributed architecture. According to the authors, in the past, safety 
monitoring systems for agricultural products had a centralized architecture and, therefore, connection could not be established between these systems. On the other hand, the distributed information service system provides public information service by acquiring and managing farming-related business data. Consumers can use this system to attain information about agricultural products and their quality.

The monitoring and control system model based on IoT is presented as a system in Figure 4. IoT devices are connected to the network through the router and have the ability to send data to the remote server on the Internet or to the Cloud services. The sensor data gathered from IoT devices are stored into the Database in the Cloud to be available for users. This access to information is gained by users from any location using their desktop computers, tablets or smart phones. Apart from this monitoring role of the system, users can control actuators via IoT devices through the Internet.

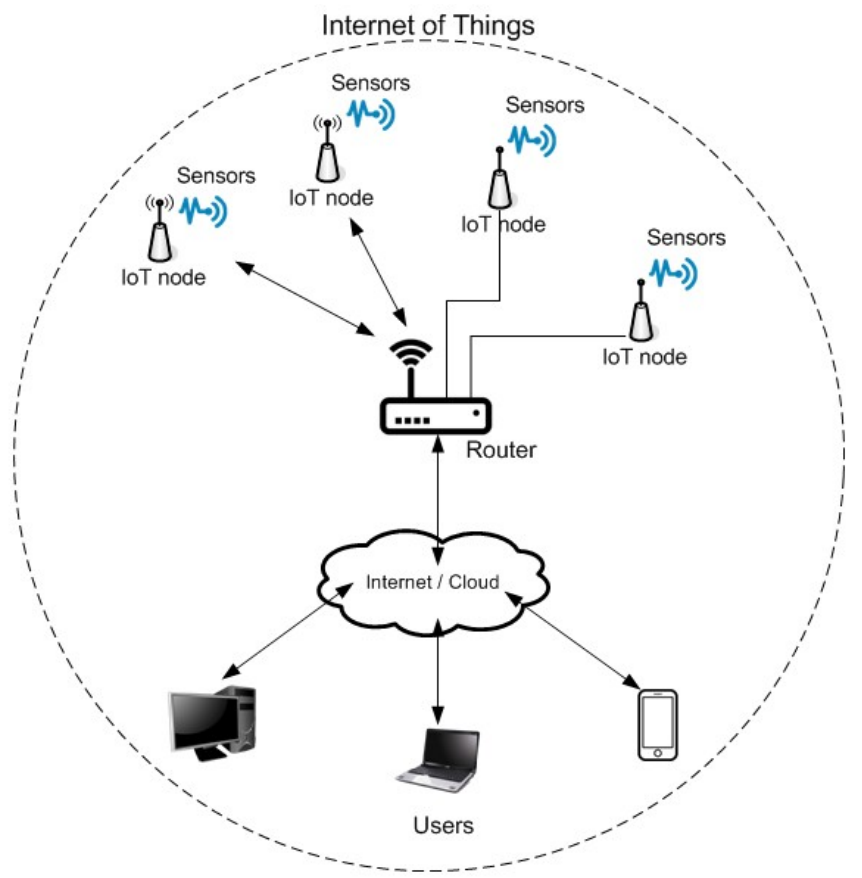

Figure 4. Internet of Things

One model of the IoT concept implemented using Arduino platforms and compatible sensors is shown in Figure 5. The computational base of the IoT node includes Arduino Uno Board on which various additional shields are pinned and onto which sensors are attached. Sensors are used for: temperature and relative humidity such as DHT11, gas emission, ir motion detection, water flow, light 
intensity etc. The data obtained by these sensors attached to analog and digital Arduino pins can be stored locally or sent to the remote server. The main board is connected to the Ethernet module using SPI communication, and may send data using HTTP protocol. In this case, the IoT device acts as the web client and when data are obtained from sensors it can submit an HTTP request that transports data to the web server on the Internet. Another role of IoT devices is that of the recipient which accepts requests from other devices. This means that the Web server is running on the device, serving requests from the network. Users can access the device and control the attached actuators such as DC motor or light intensity.

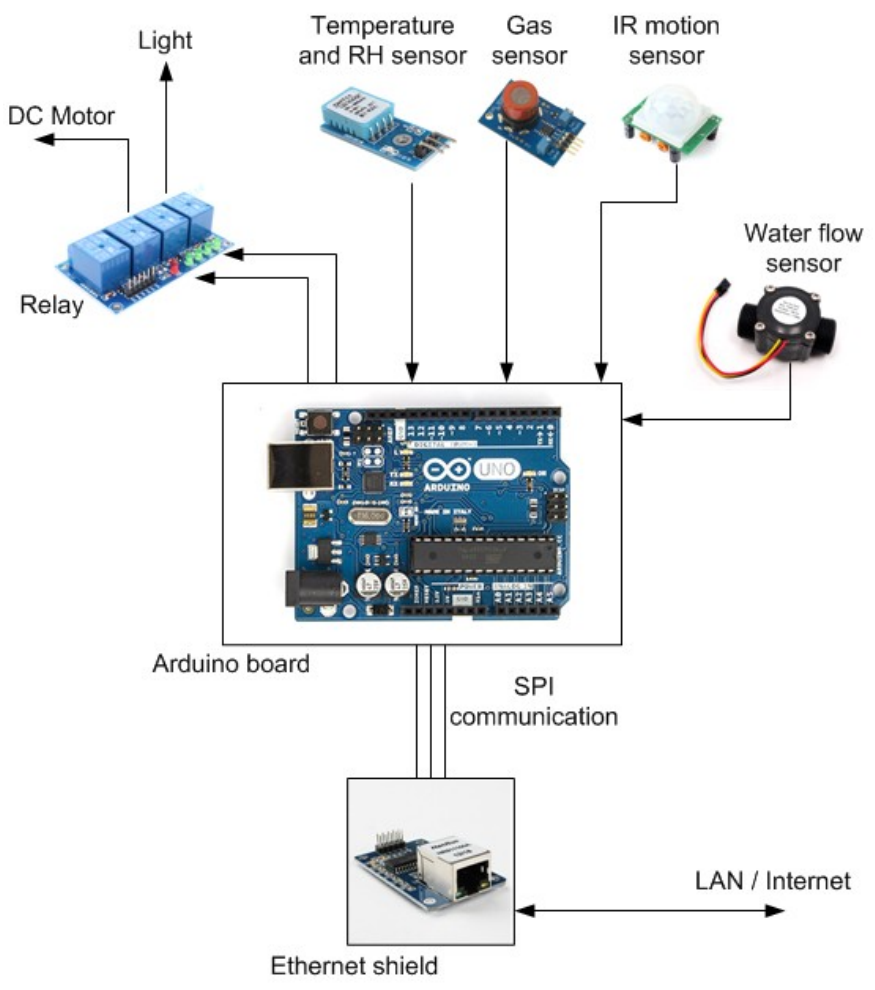

Figure 5. Node with Ethernet support

This configuration of components allows use of these devices in agricultural production. The temperature and relative humidity sensor is used to obtain information from the greenhouse. Along with the gas and light sensors, this sensor provides information about conditions in the stable. The water flow sensor is used to monitor water consumption. Also, coupled with the relay module, the output from the device can be used to start the motor or change light remotely. 


\section{Conclusion}

The IoT-based monitoring and control system model presented in this paper can be used on farms. Autonomous sensor devices have a key role in gathering data for the monitoring system, and they also send signals to the actuators in the control process. On top of this scenario, the IoT idea was introduced to connect devices through the Internet and facilitate access to information for users. The IoT based system has the ability to connect physical objects on the farm and allow their accessibility through the Internet, thus providing users with the opportunity to remotely monitor production conditions and production process. This system enables users to accomplish savings in inputs, achieve cost reduction and trace the production process on the farm.

\section{Acknowledgement}

The work presented in this paper was funded by grant TR32043 for the period 2011-2015 by the Ministry of Education, Science and Technological Development of the Republic of Serbia.

\section{References}

Arduino Ethernet. https://www.arduino.cc/en/Main/ArduinoBoardEthernet, last visited: 02.12.2015.

Chen R. (2015): Autonomous tracing system for backward design in food supply chain. Food Control, 51: 70-84.

Dang K., Sun H., Chanet J.P., Garcia-Vidal J., Barcelo-Ordinas J.M., Shi H.L., Hou K.M. (2013): Wireless multimedia sensor network for plant disease detections. NICST'2103 New Information Communication Science and Technology for Sustainable Development: France-China International Workshop, Clermont-Ferrand, France, 6.

ENC28J60 Ethernet, Arduino ENC28J60 Ethernet shield. http://www.tweaking4all.com/ hardware/arduino/arduino-enc28j60-ethernet/, last visited: 01.12.2015.

Galande S. G., Agrawal G.H., Dighe S.B. (2015): Greenhouse Microclimatic Real-Time Monitoring with the Help of NPK Sensor. International Journal of Emerging Trends in Science and Technology, 2(5): 2511-2515.

Kolban N. (2015): Kolban's book on the ESP8266. Texas, USA, http://neilkolban.com/tech/wp-content/uploads/2015/12/Kolbans-Book-onthe-ESP8266-December-2015.pdf, last visited: 02.12.2015.

Ma J., Zhou X., Li S., Li Z. (2011): Connecting Agriculture to the Internet of Things through Sensor Networks. Internet of Things (iThings/CPSCom), 
2011 International Conference on and 4th International Conference on Cyber, Physical and Social Computing, 184 - 187.

Minbo L., Zhu Z., Guangyu C. (2013): Information Service System Of Agriculture IoT. Automatika, 54(4): 415-426.

Nam H., Janak J., Schulzrinne H. (2013): Connecting the Physical World with Arduino in SECE. Columbia University Academic Commons, http://hdl.handle.net/10022/AC:P:20841

Patil V.C., Al-Gaadi K.A., Biradar D.P. Rangaswamy M. (2012): Internet of things (Iot) and cloud computing for agriculture: An overview. Proceedings of Agro-Informatics and Precision Agriculture (AIPA 2012), India, 292-296.

Shi Y., Wang Z., Wang X., Zhang S. (2015). Internet of Things Application to Monitoring Plant Disease and Insect Pests. International Conference on Applied Science and Engineering Innovation (ASEI 2015), 31-34.

Whitmore A., Agarwal A., Da Xu L. (2014): The Internet of Things-A survey of topics and trends. Information Systems Frontiers, 17(2): 261-274.

Zhang M., Li M., , Wang W., Liu C., Gao H. (2013): Temporal and spatial variability of soil moisture based on WSN. Mathematical and Computer Modelling, 58(3-4): 826-833.

Zhao J., Zhang J., Feng Y., Guo J. (2010): The study and application of the IOT technology in agriculture. Computer Science and Information Technology (ICCSIT), 2010 3rd IEEE International Conference on, 2: 462-465.

Zhou H., Liu B., Dong P. (2012): The Technology System Framework of the Internet of Things and Its Application Research in Agriculture. In Li D., Chen Y. (eds.), The Technology System Framework of the Internet of Things and Its Application Research in Agriculture, Springer Berlin Heidelberg, pp. 293-300. 
Acta Agriculturae Serbica, Vol. XX, 40 (2015) 145-153

\title{
PRIMENA IOT U NADGLEDANJU I UPRAVLJANJU PROIZVODNJE NA FARMAMA
}

\author{
Dušan Marković, Ranko Koprivica \\ Agronomski fakultet, Univerzitet u Kragujevcu, \\ Cara Dušana 34, 32000 Čačak, Srbija \\ Uroš Pešović, Siniša Ranđić \\ Fakultet tehničkih nauka, Univerzitet u Kragujevcu, \\ Svetog Save 65, 32000 Čačak, Srbija
}

\begin{abstract}
Rezime
Internet svari ili IoT (Internet of Things) predstavlja koncept koji omogućava fizičkim objekima iz realnog sveta, koji imaju računarsku i senzorsku podršku, da izvrše međusobno povezivanje i da pristupe servisima na Internetu. IoT ideja je predstavljena da poveže uređaje posredstvom Interneta i da olakša korisnicima pristup informacijama. Jedna od oblasti sa većom potencijalnom upotrebom za IoT jeste i poljoprivreda gde se može i ubuduće očekivati još šira primena. Cilj u ovom radu bio je da se predstavi IoT koncept kao osnova sistema za nadgledanje i kontrolu koji bi se upotrebili kod proizvodnih procesa na farmi. Osnovnu ulogu imaju IoT uređaji $\mathrm{i}$ fokus je na njihovoj realizaciji baziranoj na mikrokontrolerskim platformama i odgovarajućim senzorima kao što su Arduino proizvodi. Autonomni senzorski uređaji imaju ključnu ulogu u prikupljanju podataka u okviru sistema za nadgledanje i takođe imaju ulogu u kontrolnom procesu jer mogu upravljati radom aktuatora. Dati sistem zasnovan na IoT daje korisnicima priliku da nadgledaju uslove i proizvodni proces na daljinu preko svojih račuanra ili pametnih telefona. Primenom ovakvog sistema korisnici mogu postići uštede u ulaznom materijalu, smanjiti troškove i mogu nadgledati širi proces proizvodnje na farmi.
\end{abstract}

Ključne reči: Internet stvari (IoT), senzori, sistem za nadgledanje, poljoprivreda, farma. 